\title{
The mean circulation of the southwestern Mediterranean Sea: Algerian Gyres
}

\author{
P. Testor, ${ }^{1}$ U. Send, ${ }^{2}$ J.-C. Gascard, ${ }^{3}$ C. Millot, ${ }^{4}$ I. Taupier-Letage, ${ }^{4}$ and K. Béranger ${ }^{3}$ \\ Received 23 December 2004; revised 13 June 2005; accepted 17 August 2005; published 18 November 2005.
}

[1] This is a study about the general circulation of the southwestern Mediterranean Sea based on observations of currents carried out in the southwestern Mediterranean Sea in the framework of the Mass Transfer and Ecosystem Response (MATER) program (EEC/ MAST3 program). From July 1997 to August 2002, profiling floats (MEDPROF experiment), isobaric floats (LIWEX experiment), and moored current meters (ELISA experiment) give evidence of two large-scale barotropic cyclonic circulations, the herecalled Western and Eastern Algerian Gyres, centered around $\left[3730^{\prime} \mathrm{N}, 230^{\prime} \mathrm{E}\right]$ and $\left[3830^{\prime} \mathrm{N}\right.$, $\left.600^{\prime} \mathrm{E}\right]$, respectively. These gyres have typical horizontal scales of $100-300 \mathrm{~km}$ and are characterized by orbital velocities of about $5 \mathrm{~cm} / \mathrm{s}$ corresponding to rotational periods of about 4 months. They are strongly related to the bottom topography of the basin and to the planetary vorticity gradient: closed $f / H$ isocontours $(f$ is the planetary vorticity, $H$ the water depth) correspond to the locations of the gyres and favor such circulations as free geostrophic modes. A linear and barotropic model is used to investigate the possibility of wind driving, but the results suggest that the wind stress is not responsible for establishing such circulations. The boundary currents flowing along the continental slope of Africa, Sardinia, and the Balearic Islands are proposed to be the main drivers of these gyres.

Citation: Testor, P., U. Send, J.-C. Gascard, C. Millot, I. Taupier-Letage, and K. Béranger (2005), The mean circulation of the southwestern Mediterranean Sea: Algerian Gyres, J. Geophys. Res., 110, C11017, doi:10.1029/2004JC002861.

\section{Introduction}

[2] The general oceanic circulation in the Mediterranean Sea is partly controlled by the density gradient and sea level differences between the Atlantic Ocean and the Mediterranean Sea and by water masses transformation inducing an active thermohaline component in the circulation [Bryden and Stommel, 1984; Robinson and Golnaraghi, 1994]. Both components are generating a very dynamic surface inflow of Atlantic water masses and deep outflow of Mediterranean water masses through the Strait of Gibraltar. In this context, the southwestern Mediterranean Sea is an important transit region where (1) fresh Atlantic water entering the Mediterranean Sea through the Strait of Gibraltar and flowing eastward at surface along the slope is modified and transformed and (2) intermediate and deep Mediterranean waters formed in winter in the northern parts of the western and eastern Mediterranean basins, respectively, are flowing westward at depth toward the Strait of Gibraltar.

\footnotetext{
${ }^{1}$ Leibniz-Institut für Meereswissenschaften (IFM-GEOMAR), Kiel, Germany.

${ }^{2}$ Scripps Institution of Oceanography (SIO), University of California, San Diego, La Jolla, California, USA.

${ }^{3}$ Laboratoire d'Océanographie et de Climatologie: Approche Expérimentale et Numérique (LOCEAN), Université Pierre et Marie Curie, Paris, France.

${ }^{4}$ Laboratoire d'Océanographie et de Biogéochimie (LOB), Université de la Méditerranée, Antenne de Toulon, France.
}

Copyright 2005 by the American Geophysical Union. 0148-0227/05/2004JC002861
[3] The aim of the Mediterranean Targeted Project MATER (Mass Transfer and Ecosystem Response) was to provide a better understanding of the functioning of the Mediterranean Sea through interdisciplinary studies. In this framework, Lagrangian and Eulerian observations of currents and water masses physical properties were carried out in the western basin in order to study the general circulation and mesoscale features in this region.

[4] Although the western Mediterranean sea has been intensively studied in recent years, a basin-wide view of its circulation is still incomplete. Satellites (IR, visible, and microwave) can provide large-scale observations of the surface circulation only, and concerning altimetry, only the variable part of the sea surface topography can be remotely sensed (geoid problem). Past ship observations allowed to track intermediate and deep water mass pathways based on their hydrographic properties, while moorings deployed in this region mainly addressed the importance of eddies. On the basis of these observations, a general picture of the circulation in this region could be drawn. It consists of a cyclonic boundary circulation along the continental slopes of all water masses as a result of the Coriolis effect [Millot, 1987, 1999], but still little is known about the circulation in the basin interior and eddies are supposed to drive it according to Millot [1999].

[5] In this context we present here two large-scale circulation patterns in the western Mediterranean basin which could not be identified until recent intensive observations were completed over a long period of time in the framework of the MATER program, with deep Lagrangian floats 


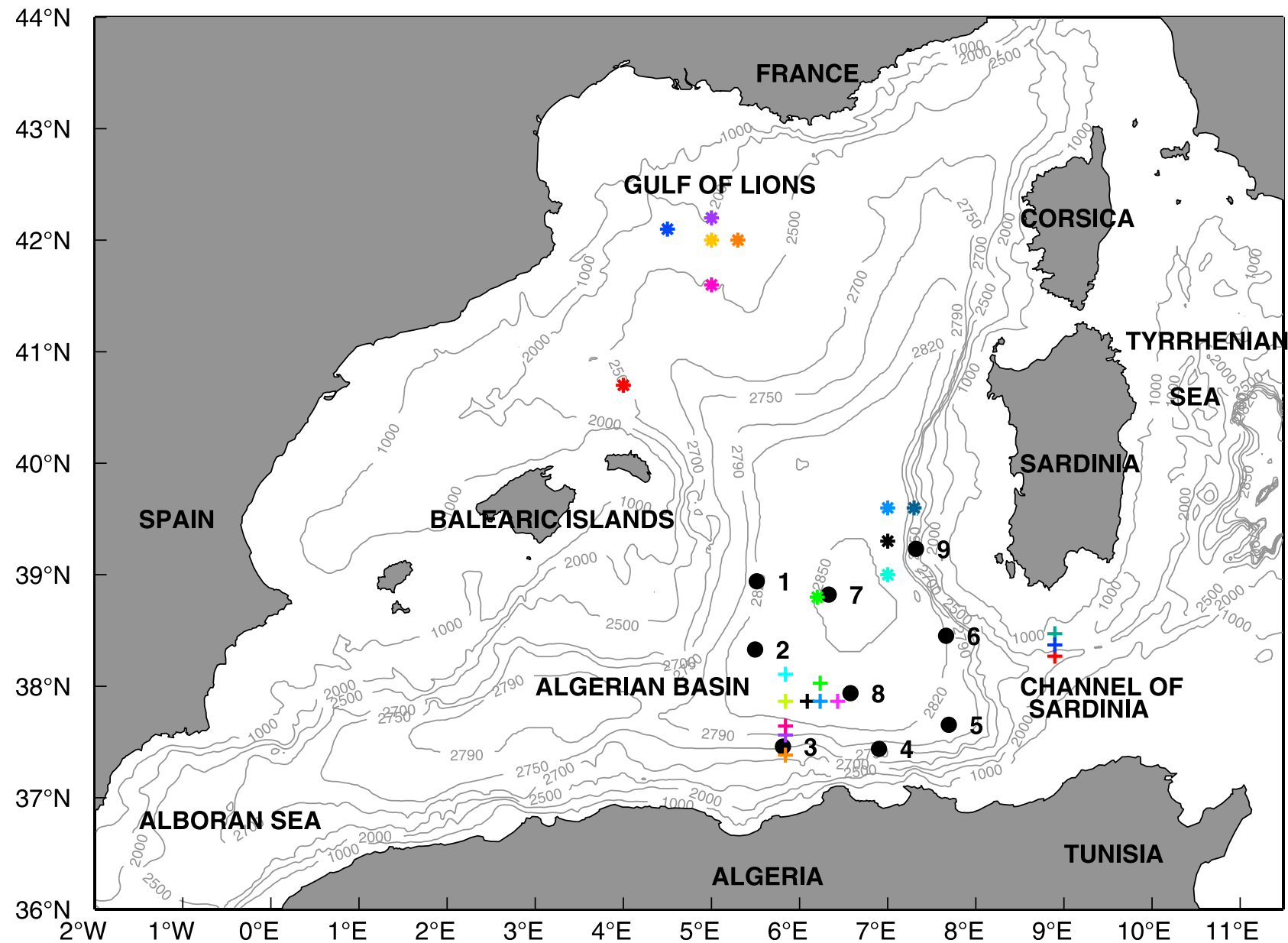

Figure 1. Locations of the moorings (dots) and deployment positions of RAFOS floats (crosses) and profiling floats (stars) analyzed in this study (and shown in Figures 2 and 4 using the same color code). Bathymetric contours are shown in meters. Note the irregular spacing between isobaths focusing on the deep topography.

(LIWEX and MEDPROF experiments) and a large-scale moored current meters array (ELISA experiment). These data reveal the existence of two large-scale cyclonic gyres embedded in the along-slope general circulation. We document their strong barotropic component and relate them to constraints resulting from a combined effect of the basin topography and planetary vorticity. Then, the origin of these newly discovered circulations is investigated by using atmospheric and hydrographic data.

\section{Study Area}

[6] Presently, the knowledge about the circulation in the southwestern Mediterranean Sea is largely restricted to the circulation of the surface modified Atlantic water (AW) and the boundary currents [Millot, 1987, 1999].

[7] Basically, AW enters into the Mediterranean Sea through the Strait of Gibraltar and follows a cyclonic path while undergoing modification due to air-sea interactions and mixing with local waters. The inflow of AW is oriented eastward along the African continental slope and crosses the Channel of Sardinia along the Tunisian coast toward the Tyrrhenian and the eastern Mediterranean basins (Figure 1). It is approximately $30-50 \mathrm{~km}$ wide and $200-400 \mathrm{~m}$ deep near the slope [Benzohra and Millot, 1995a] and it is commonly named the Algerian Current off Algeria where it displays very specific characteristics [Millot, 1985]. A westward core of old and saltier AW exiting from the southern Tyrrhenian basin has been observed close to the southern slope of Sardinia [Bouzinac et al., 1999; Astraldi et al., 2002]. Upwelling in the southern coast of Sardinia can also account for occasionally westward flows of AW [Perkins and Pistek, 1990].

[8] The unstable character of the Algerian Current leads to meanders a few tens of kilometers in wavelength, which may develop into eddies downstream of $1-2^{\circ} \mathrm{E}$. These eddies have a clear surface signature that can be tracked by satellite imagery (infrared, visible, and altimetry). Both cyclonic and anticyclonic eddies are generated and propagate downstream eastward at approximately $3-5 \mathrm{~cm} / \mathrm{s}$ [Millot, 1985; Font et al., 1998]. Only anticylonic structures seem to grow and become large and energetic. When this occurs (few times per year), these structures are usually called Algerian Eddies (AEs).

[9] Their diameter, vertical extent, and kinetic energy fluctuate in time [Millot, 1997], but the general characteristics of these AEs are a diameter of $50-200 \mathrm{~km}$ and associated surface orbital velocities of more than $50 \mathrm{~cm} / \mathrm{s}$ 
implying a rotational period of a few weeks [Taupier-Letage et al., 2003]. A clear signature of AEs can always be observed in the surface layer of AW $(0-300 \mathrm{~m})$, and sometimes their vertical extent can reach $1000 \mathrm{~m}$ [Millot, 1991; Benzohra and Millot, 1995b] or even the bottom at around $2800 \mathrm{~m}$ [Ruiz et al., 2002; Taupier-Letage et al., 2003; Millot and Taupier-Letage, 2005]. The surface circulation in this region is usually characterized by two or three large AEs at any one time. AEs dominate the surface circulation in the basin interior and are speculated to drive the circulation of intermediate and deep water masses as well, when they have a large vertical extent.

[10] Their lifetime can range from several months [Millot, 1987; Taupier-Letage and Millot, 1988; Millot, 1997] up to 3 years [Puillat et al., 2002]. Hence they can reach the entrance of the Channel of Sardinia where they leave the slope, possibly due to interaction with the bottom topography [Millot, 1987, 1991; Fuda et al., 2000]. Then, they drift northward along the slope of Sardinia and generally leave the slope around $40^{\circ} \mathrm{N}$ propagating in the open sea, following a cyclonic path in the basin [Millot, 1987; Vignudelli, 1997; Ayoub et al., 1998; Bouzinac et al., 1999; Fuda et al., 2000]. The propagation speed is usually a few $\mathrm{cm} / \mathrm{s}$ but AEs can sometimes remain motionless for weeks or months (up to 9 months) [Taupier-Letage and Millot, 1988]. The time to cover a complete loop in this basin is about 1 year and they can repeat several loops along this circuit due to their long lifetime [Puillat et al., 2002].

[11] Other water masses which can be found in the southwestern basin result from the intermediate and deep interbasin exchanges between the Algerian and the Tyrrhenian basins through the Channel of Sardinia. Relatively warm and salty water masses formed in the eastern Mediterranean basin flow out through the Strait of Sicily and cascade across the slope in the Tyrrhenian Sea. A maximum of temperature and salinity around 200-300 m depth still characterizes the Levantine Intermediate Water (LIW), and Tyrrhenian Deep (or Dense) Water (TDW) denotes the water masses situated just below $(500-1500 \mathrm{~m})$. These waters flow into the Algerian basin south of Sardinia and turn to the North following the Sardinian slope [Millot, 1987; Hopkins, 1988; Rhein et al., 1999]. On the other side of the Channel of Sardinia, WMDW and highly modified LIW and TDW (due to mixing with waters in the AlgeroProvençal basin [Millot, 1999; Bouzinac et al., 1999; Sammari et al., 1999]) follow the same path as AW toward the east and enter into the Tyrrhenian Sea.

[12] Patches of LIW exhibiting temperature maxima around $13.8^{\circ} \mathrm{C}$ (which is the temperature characterizing the LIW in the boundary circulation southwest of Sardinia) have been observed in the interior of the Algerian basin [Millot, 1987, 1999; Fuda et al., 2000; Millot and TaupierLetage, 2004]. They have been interpreted as resulting from an injection of LIW from the LIW vein which flows along the Sardinian slope. The mechanism appears to be related to the AEs which can have a deep influence and trap patches of LIW from the LIW vein, carrying them toward the center of the basin [Millot, 1999; Millot and Taupier-Letage, 2005].

[13] As an alternative mechanism, this patchiness in the basin interior could also be due to the formation of eddies at the southwest corner of Sardinia. During the MATER
Table 1. Distributions of the Measurements of the Modulus of the Velocity in the Southwestern Mediterranean Sea (South of $40^{\circ} \mathrm{N}$ ) by Layers and Instruments

\begin{tabular}{lcc}
\hline \multicolumn{1}{c}{ Section } & Mean $(\mathrm{U}), \mathrm{cm} / \mathrm{s}$ & Max $(\mathrm{U}), \mathrm{cm} / \mathrm{s}$ \\
\hline RAFOS $(600 \mathrm{~m})$ & $4.40 \pm 2.75$ & 15.91 \\
Profiling $(1200$ and $2000 \mathrm{~m})$ & $3.75 \pm 2.46$ & 12.00 \\
Moored current meters $(100 \mathrm{~m})$ & $18.13 \pm 12.61$ & 62.77 \\
Moored current meters $(350 \mathrm{~m})$ & $4.77 \pm 3.05$ & 14.73 \\
Moored current meters $(1000 \mathrm{~m})$ & $3.99 \pm 2.59$ & 15.32 \\
Moored current meters $(1800 \mathrm{~m})$ & $4.47 \pm 2.98$ & 15.00 \\
Moored current meters $(2700 \mathrm{~m})$ & $5.72 \pm 3.43$ & 15.82 \\
\hline
\end{tabular}

experiment, RAFOS floats drifting at around $600 \mathrm{~m}$ depth in the eastern part of the Algerian basin revealed a largescale cyclonic circulation in the interior of the basin, the socalled Algerian Gyre [Gascard et al., 1999; Testor and Gascard, 2005]. This gyre separating from the slope at the southwest corner of Sardinia, induces the formation of Sardinian Eddies (SEs) [see Testor and Gascard, 2005] in contrast with AEs which are formed by the instabilities of the Algerian Current. During their formation, the SEs trap LIW and TDW constrained to circulate between the gyre and the slope and are believed to transport a significant part (estimated to be around 50\%) of these water masses entering the western basin through the Channel of Sardinia, toward the center of the basin [Testor and Gascard, 2005].

\section{Data Set Presentation}

[14] The collection of current and hydrographic data involved the IFM-Kiel, the LODYC-Paris, and the LOB/ COM-Toulon [MAST3, 1999], in the deployment of profiling floats, RAFOS floats, and moored current meters, respectively (Figure 1). The RAFOS and profiling floats in MATER were intentionally designed and coordinated to sample the different layers of the LIW, the TDW, and the WMDW, in order to complement one another. Moorings were deployed to give Eulerian information over the whole water column. In addition, around 300 CTD casts were performed during the five cruises needed for the deployment/recovery operations. For the analyses presented here, CTD casts were treated like floats profiles and together only those shown later in Figure 6 have been used.

\subsection{Moored Current Meters}

[15] An array of nine moorings was deployed in the eastern Algerian basin in July 1997 (ELISA-1 cruise). As indicated by the ELISA Web site (available at http:// www.com.univ-mrs.fr/LOB/ELISA/), each mooring was equipped with four or five current meters located at 100 , $350,1000,1800$, and $2700 \mathrm{~m}$ depth (around $100 \mathrm{~m}$ above the bottom) and provided time series of currents (Table 1). All the moorings were recovered 1 year later in July 1998.

[16] Owing to defects of all the RCM9 (not enough reflectors at the $350-\mathrm{m}$ level where they were set to sample LIW) and most of the MORS current meters, 14 time series out of 40 are lacking. In the following, standard deviations of the velocities which are shown later in Figure 3 were computed from the velocity time series at the locations of the moorings along two directions: one follows the direction of the mean flow and the other is perpendicular. 


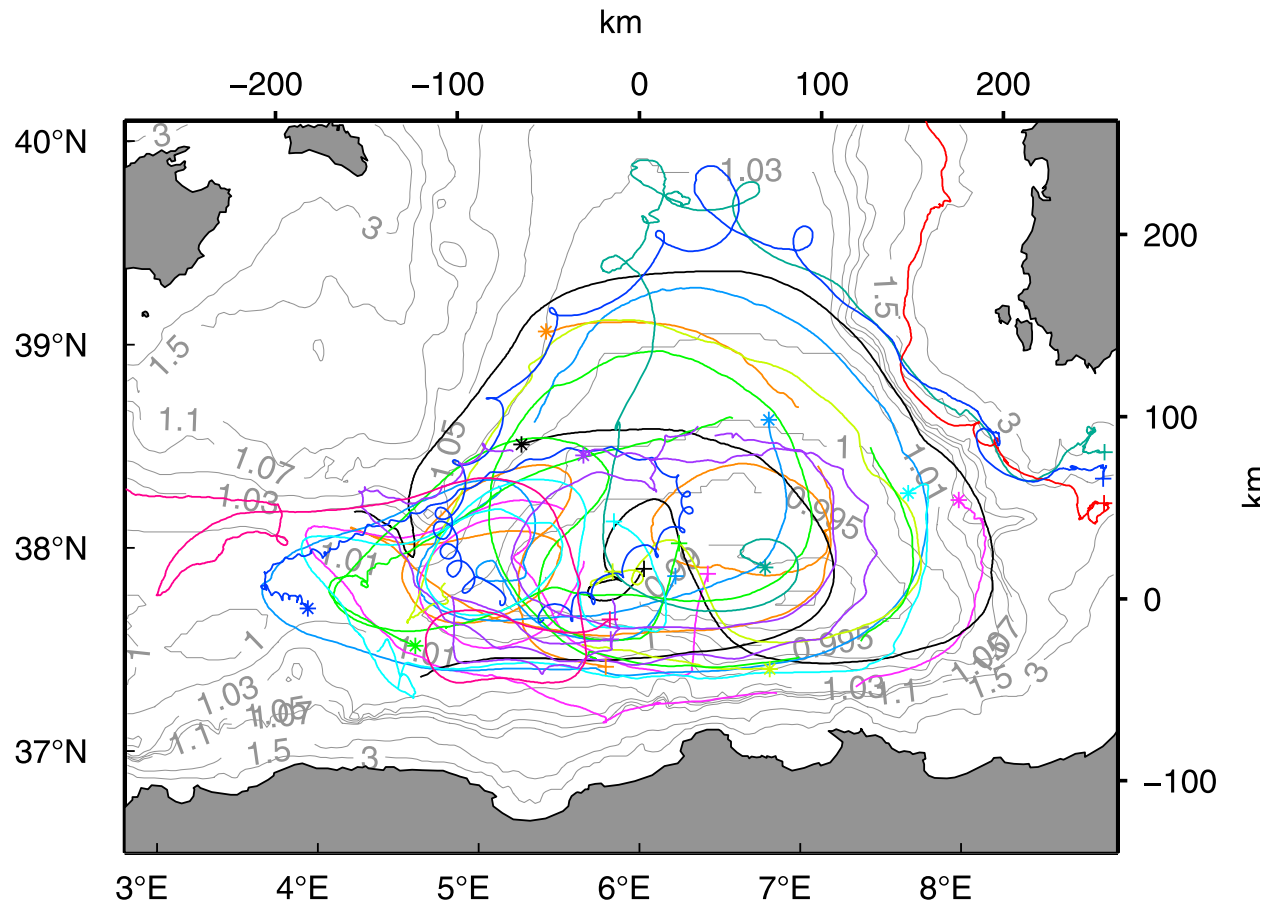

Figure 2. Trajectories of the RAFOS floats at around $600 \mathrm{~m}$ depth from July 1997 until 24 June 1998 superimposed on $f / H$ contours ( $f$ being the planetary vorticity and $H$ the water depth). Values are normalized by $f_{0}$ at $37^{\circ} 45^{\prime} \mathrm{N}$ and $H_{0}=2800 \mathrm{~m}$ characterizing the region over the abyssal plain. The first positions are indicated by crosses.

\subsection{RAFOS Floats}

[17] Fifteen subsurface Lagrangian floats were acoustically tracked from 14 July 1997 to 24 June 1998. These socalled RAFOS floats are isobaric like Swallow floats [Swallow, 1955] and drift following the horizontal currents at a predetermined and quasi-constant depth during a predetermined time period. At the end of their mission, they drop a dead weight and rise to the surface to transmit the data they have collected via satellite.

[18] They were programmed and ballasted to drift in the intermediate layer at around $400 \mathrm{~m}$ depth for 1 year. Very sensitive ballasting is needed, and they ended up somewhat deeper than expected at around $600 \mathrm{~m}$ depth. They were localized by acoustic triangulation using the array of ELISA moorings that were also equipped with acoustic sources transmitting 6 times per day. The floats recorded the arrival time of these signals in order to be located a posteriori. The mean absolute accuracy for float positioning is about $2 \mathrm{~km}$ but relative precision is much better. They also measured in situ temperature and pressure every 4 hours.

[19] The floats were deployed during the ELISA-1 cruise in July 1997. Ten floats were launched in the basin interior, five south of Sardinia in the Levantine vein inflowing in the Algerian basin. At the end of their missions, 12 floats actually transmitted data via satellite and these are shown in Figures 1 and 2. They were recovered at the end of the experiment which allowed the calibration of the sensors. The floats were positioned every 4 hours each time the sound sources emitted using the travel times between each floats and the different acoustic sources. Only a slight filtering was applied to remove the inertial period (low-pass filter with a cutoff frequency corresponding to the inertial period which is $19-20$ hours in that region). Velocity measurements along float trajectories could be calculated by differencing the positions (Table 1).

\subsection{Profiling Floats}

[20] Seventeen profiling floats (7 SOLO and 10 ALACE floats) were deployed in the western Mediterranean Sea (M. Reich, personal communication, 2001). These floats are designed to follow the horizontal currents at a constant depth and to rise to the surface at fixed time intervals by controlling their buoyancy. At the surface, their position is determined via an Argos transmitter and the data they have collected during their ascent (temperature and salinity measurements) are transmitted, before returning to depth and starting a new cycle. These floats thus provide both hydrographic profiles and estimations of deep velocities by differencing the positions (Table 1). Velocity measurements have been discarded when floats are likely to have been running aground between two positions at surface. For this experiment, the cycle length for the profiling floats were set to 8 days, including 3 hours of data transmission. A particularly high data transmission rate was used in order to minimize the time spent at the surface and the risk of running aground during subsequent cycles (which is high in this enclosed sea). The SOLO floats drifted around $1200 \mathrm{~m}$ depth (TDW layer) and the ALACE floats at around $2000 \mathrm{~m}$ depth (WMDW layer). With the last float ending in August 2002, they provided together around 1300 profiles in the whole western Mediterranean Sea.

[21] The seven SOLO floats were launched during the Poseidon 234 cruise in October-November 1997 all around the basin. Then, six and four ALACE floats were deployed 


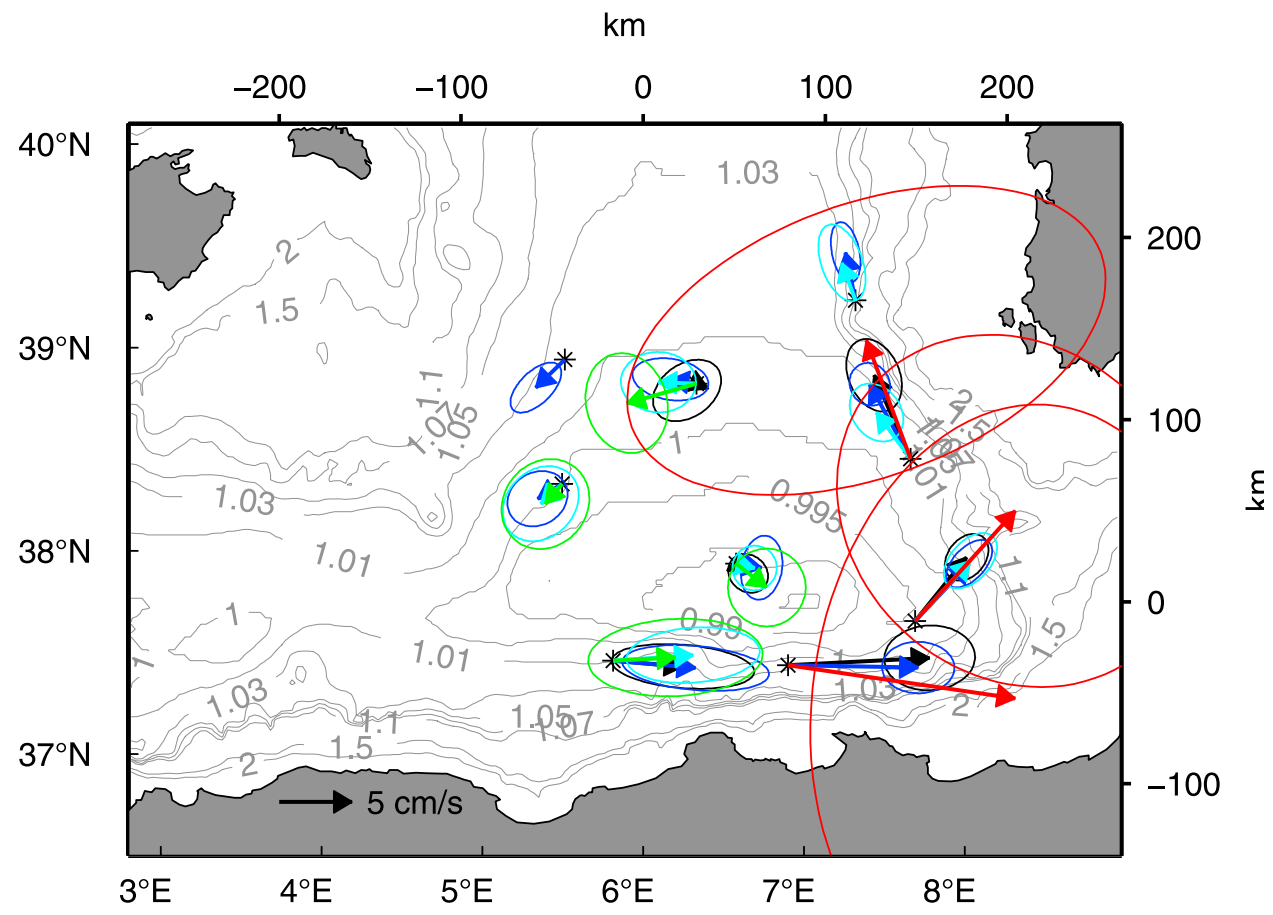

Figure 3. Mean currents (arrows) and standard deviations (ellipses) around the end point of the arrows over the period July 1997 to July 1998 from moored current meters at $100 \mathrm{~m}$ (red), at $350 \mathrm{~m}$ (green), $1000 \mathrm{~m}$ (cyan), $1800 \mathrm{~m}$ (blue), and $2700 \mathrm{~m}$ (black) depth, superimposed on $f / H$ contours normalized by $f_{0}$ at $37^{\circ} 45^{\prime} \mathrm{N}$ and $H_{0}=2800 \mathrm{~m}$.

in February 1999 in the Gulf of Lions and in October 1999 west of Sardinia, respectively. Their lifetime ranged from 1 month up to almost 5 years.

\section{Large-Scale Permanent Cyclonic Circulations}

[22] The dominant pattern revealed by the Lagrangian trajectories of the RAFOS floats was a large-scale cyclonic circulation in the interior of the eastern part of the basin throughout the whole experiment from July 1997 to June 1998 (Figure 2). This basin scale circulation has an elliptical shape centered at $\left[38^{\circ} 30^{\prime} \mathrm{N}, 6^{\circ} \mathrm{E}\right]$. It is characterized by a west-east extent of about $250 \mathrm{~km}$ and a north-south one of $150-200 \mathrm{~km}$. The velocities are typically $5-10 \mathrm{~cm} / \mathrm{s}$ at the periphery of the circulation, and the corresponding rotational period is about $3-4$ months.

[23] During the same period and in the same region, the mean currents observed at mooring sites show similar circulations at all depths (Figure 3). The fluctuations are generally small below $350 \mathrm{~m}$ depth, indicating that the velocities measured by the moored current meters generally do not differ much in intensity and direction from the average ones (see also the progressive vector diagrams and average velocities presented by Millot and TaupierLetage [2005]). This is not the case in the surface layer which is dominated by intense mesoscale currents: while the AEs velocity signature in the deep and intermediate layers is weak, order of a few $\mathrm{cm} / \mathrm{s}$, they can induce mesoscale currents order of $50-100 \mathrm{~cm} / \mathrm{s}$ in the surface layer of AW.

[24] The profiling floats show not only a similar circulation at 1200 and $2000 \mathrm{~m}$ depth in the eastern part of the Algerian basin (Figure 4), but also another large-scale cyclonic circulation located to the west, centered at $\left[37^{\circ} 30^{\prime} \mathrm{N}, 2^{\circ} 30^{\prime} \mathrm{E}\right]$. This circulation also has an elliptical shape extending approximately $300 \mathrm{~km}$ along the west-east direction and $150 \mathrm{~km}$ along the south-north one. The associated velocities are around $5 \mathrm{~cm} / \mathrm{s}$ at its periphery as well, and its rotational period is $4-5$ months.

[25] Figure 5 shows the circulation in the Algerian basin over different periods of time. Even if the spatiotemporal sampling of the profiling floats is too coarse to describe any temporal changes, the typical scales (the horizontal extents, velocities, and the rotational period) appear to be about the same from year to year for both circulations. The eastern one was sampled by RAFOS floats and moored current meters from July 1997 to July 1998 and by profiling floats during 5 years from November 1997 until August 2002. The western circulation was sampled by profiling floats during 2.5 years from December 1999 until June 2002. These data suggest that the circulation described are permanent features.

\section{Barotropic Circulations}

[26] All the current measurements indicate the same cyclonic patterns of general circulation at all depths, suggesting two strongly barotropic circulations. In addition, the observed velocities closely follow $f / H$ isocontours which are closed in that region (Figures 2, 3, and 4).

[27] Two relative minima in the $f / H$ field located in the basin interior make the $f / H$ contours coincide with the two cyclonic circulations. This is not the case for bathymetric contours, especially in the northeastern part of the Algerian basin. Note the differences in shape between this $f / H$ field and the bathymetry $H$ shown in Figure 1. In the west, the meridional distance between the continental slopes of Africa 


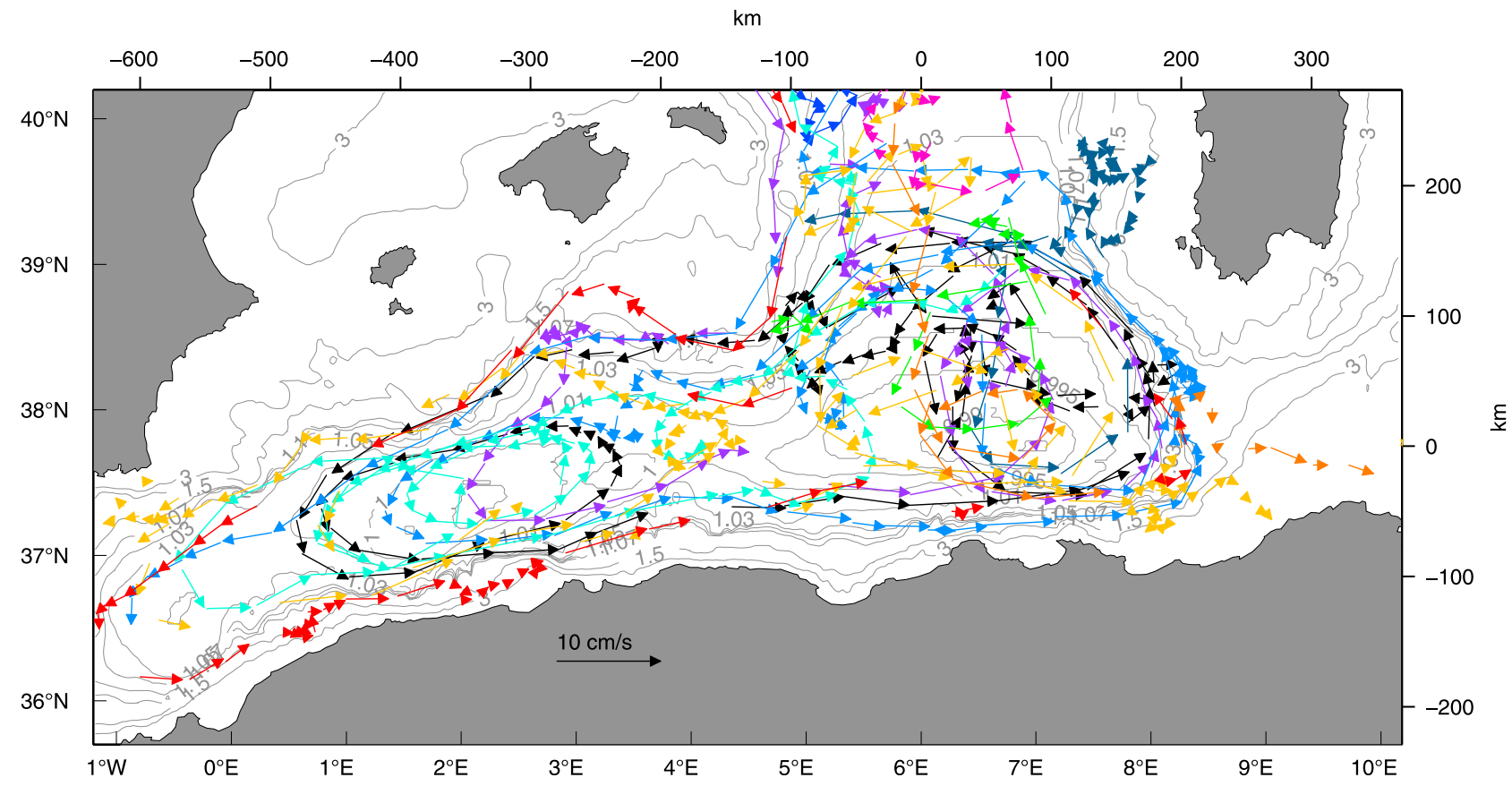

Figure 4. Trajectories of profiling floats drifting at 1200 and $2000 \mathrm{~m}$ depth superimposed on $f / H$ contours normalized by $f_{0}$ at $37^{\circ} 45^{\prime} \mathrm{N}$ and $H_{0}=2800 \mathrm{~m}$. One color for each float. Arrows indicate the drift at depth during one cycle ( 8 days).

and the Balearic Islands is small so $f$ is almost constant and the $f / H$ contours are very similar to the bathymetric ones. In the east, however, variations of $f$ are very important for determining the shape of the $f / H$ contours, especially the northern edge of the contours (above the abyssal plain), even though the meridional distances considered here are quite small.

[28] The movement of the fluid appears to be mostly constrained by a barotropic potential vorticity conservation dominated by the planetary vorticity and topographic effects (first-order barotropic potential vorticity balance). This is consistent with the flow being rather depth-independent and the Rossby number characterizing each of there circulations $R_{o} \sim \frac{U}{f L} \sim \frac{\zeta}{f}$ being of the order of $0.01(U \sim 10 \mathrm{~cm} / \mathrm{s} ; f$ at $\sim 38^{\circ} \mathrm{N} ; L \sim 100 \mathrm{~km}$ where $U$ is the velocity scale, $L$ is the horizontal scale, and $\zeta$ is the relative vorticity).

[29] Thus the Algerian basin appears to be characterized by two cyclonic large-scale circulations, which are mainly barotropic and will be called hereafter the Western and Eastern Algerian Gyres. The barotropic character is worth noting since the Algerian basin is strongly stratified and could be considered as a two-layer ocean domain with relatively fresh AW lying above the salty and much denser Mediterranean waters: one would therefore have expected a general circulation characterized by a strong first baroclinic mode.

\section{Two Different Regimes}

[30] In order to be able to investigate the hydrographic structure in the southwestern Mediterranean Sea in spite of the coarse spatiotemporal coverage of the data, $f / H$ coordinates can be used to collapse the data onto single sections. Figures 7 and 8 display temperature profiles (from profiling floats and CTD casts) between 1997 and 2002 carried out in selected areas across the continental slope (Figure 6), for the eastern and western parts of the basin, respectively. They are plotted according to the $f / H$ value at the position of the cast. In order to have a better visual representation of the distributions, we have projected all the profiles onto average sections following $f / H$ contours. Thus the casts are plotted according to distance, like "classical" hydrographic sections. This considers the barotropic potential vorticity conservation shown in the previous section.

[31] On the basis of all these potential temperature sections, water with distinct properties can be observed at intermediate levels in the vicinity of the continental slope (this corresponds approximately to $(f / H) /\left(f_{0} / H_{0}\right)>1.1$ for the Eastern Algerian Gyre and $(f / H) /\left(f_{0} / H_{0}\right)>1.0$ for the Western Algerian Gyre marked by thick dashed lines in both figures). Three main hydrographic features of this slope regime can be identified, which are parts of the general along slope boundary circulation of the whole western Mediterranean Sea:

[32] 1. At intermediate levels $(200-1000 \mathrm{~m})$ there are relatively warm waters. They are characterized by highest temperatures along the continental slope of Sardinia (Figure 7a), the maximum temperature here being about $13.8^{\circ} \mathrm{C}$ near $250 \mathrm{~m}$ depth. These distinct waters are typical of LIW just entering into the Algerian basin through the Channel of Sardinia from the Tyrrhenian Sea.

[33] 2. Cold anomalies of temperature at subsurface depth ( $\sim 200 \mathrm{~m})$ can be observed, especially southwest of the Balearic Islands (Figure 7b). Here, the corresponding temperature minima are around $13{ }^{\circ} \mathrm{C}$ which indicate the presence of Winter Intermediate Water arriving into this region from the northern part of the western Mediterranean basin where it is formed [Lacombe and Tchernia, 1960; Gascard and Richez, 1985; Salat and Font, 1987; Perkins and Pistek, 1990; Sparnocchia et al., 1995; Fuda et al., 2000]. This is 


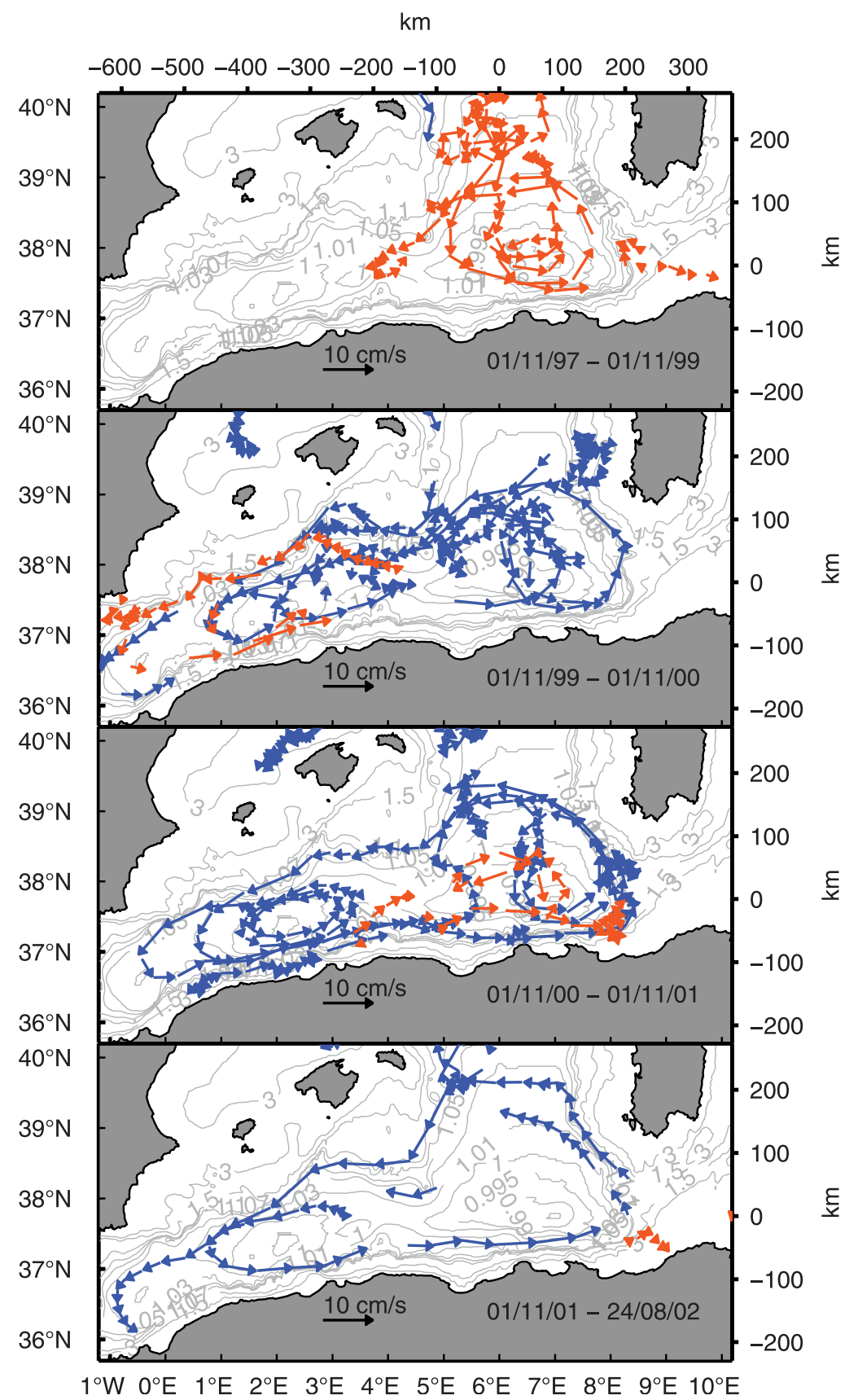

Figure 5. Trajectories of profiling floats drifting at 1200 (orange) and $2000 \mathrm{~m}$ depth (blue) superimposed on $f / H$ contours normalized by $f_{0}$ at $37^{\circ} 45^{\prime} \mathrm{N}$ and $H_{0}=2800 \mathrm{~m}$. Arrows indicate the drift at depth and during one cycle ( 8 days). The corresponding time periods are indicated on each subplot.

less clear on Figure $8 \mathrm{~d}$ but one can still find such cold anomalies mostly on the northern side.

[34] 3. Along the Algerian slope, the boundary circulation can be identified in the intermediate and deep layers on both Figures 7c and 8e: the isotherms are less deep near the coast below the LIW temperature relative maximum. LIW is very eroded here with temperature maxima much less pronounced. These waters have undergone mixing with colder WIW and WMDW longer than the other LIW that one could find in that region. This is consistent with LIW not entirely flowing out of the Mediterranean Sea through the Strait of Gibraltar but partially recirculating and flowing eastward along the slope under the well-documented eastward inflow of AW along Africa.

[35] In contrast, in the basin interior the temperature distributions at intermediate level are very patchy with "random" distributions of relative maxima and minima of temperature corresponding to LIW and WIW signatures. The water properties are not as pronounced as at the boundaries depicted above, indicating longer residence times. Note that the properties of temperature in the basin interior are about the same for each gyre as indicated by the distributions of the temperature averaged over the layer 200-500 $\mathrm{m}$ on each section (Table 2). 
$40^{\circ} \mathrm{N}$

$39^{\circ} \mathrm{N}$
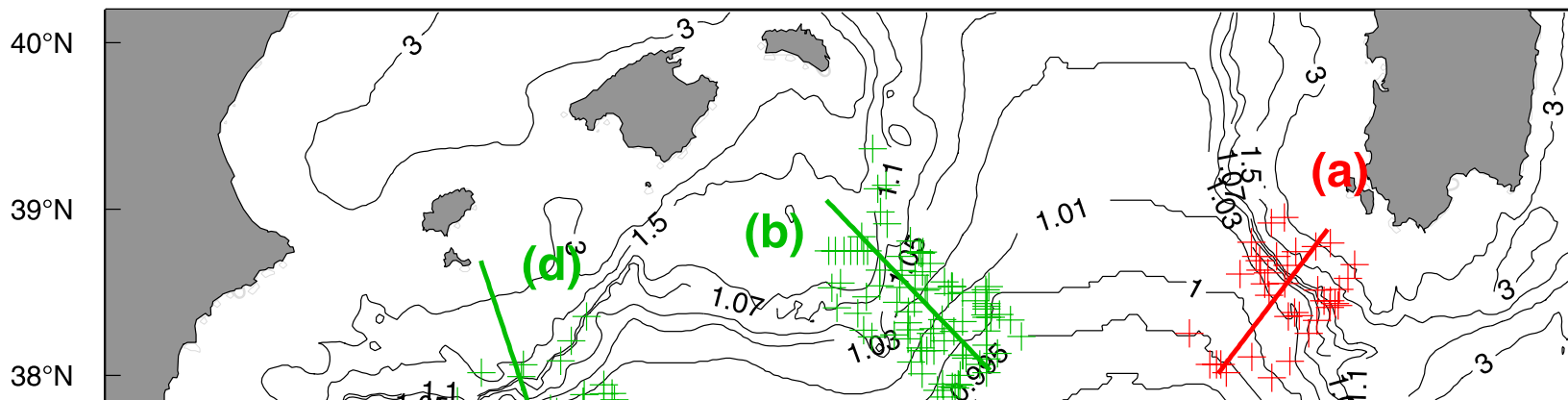

(b) $S 0$

\section{$37^{\circ} \mathrm{N}$}
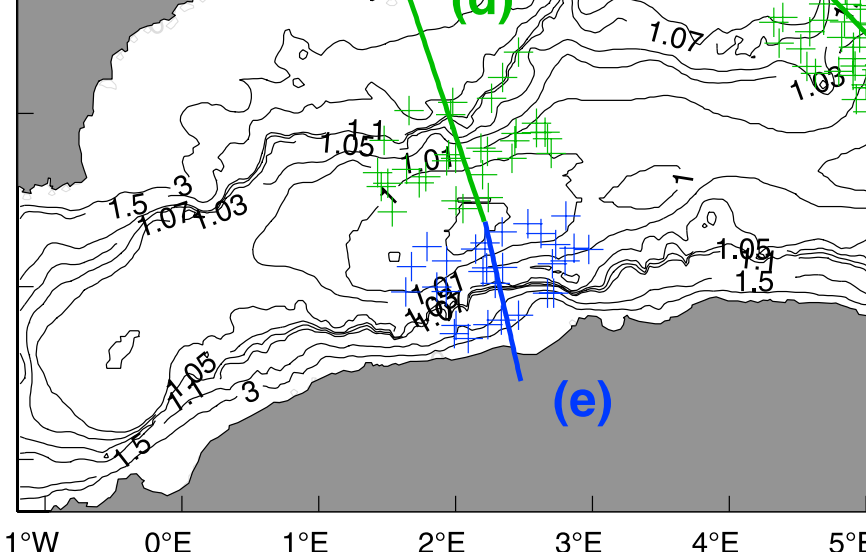

Figure 6. Locations of the profiles and the sections presented on Figures 7 and 8 , over $f / H$ contours normalized by $f_{0}$ at $37^{\circ} 45^{\prime} \mathrm{N}$ and $H_{0}=2800 \mathrm{~m}$.

\section{$\begin{array}{llllllllll}12.8 & 12.9 & 13 & 13.1 & 13.2 & 13.3 & 13.4 & 13.5 & 13.6 & 13.7^{\circ} \mathrm{C}\end{array}$}

(a)

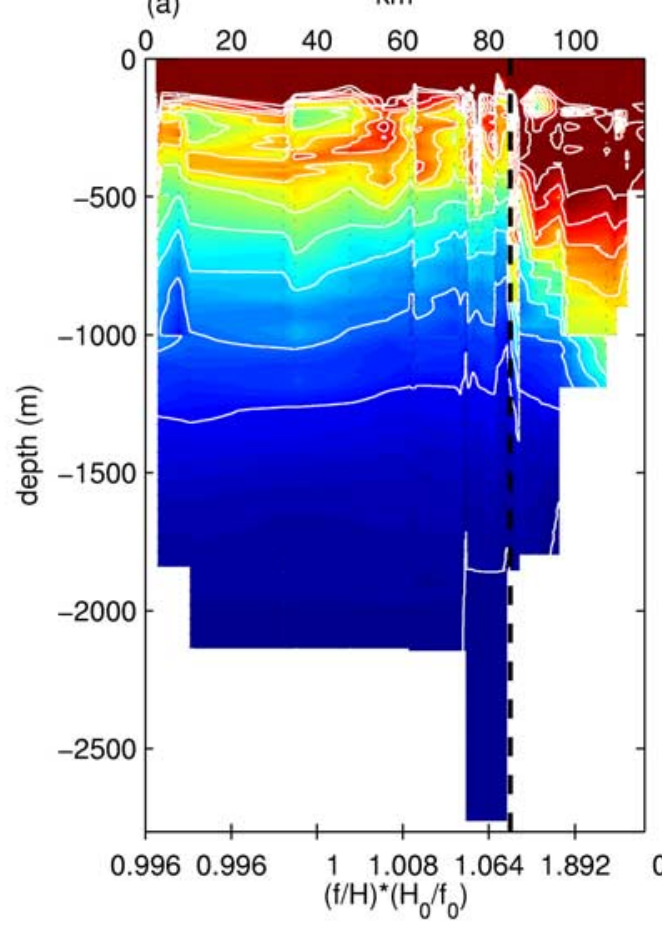

(b)

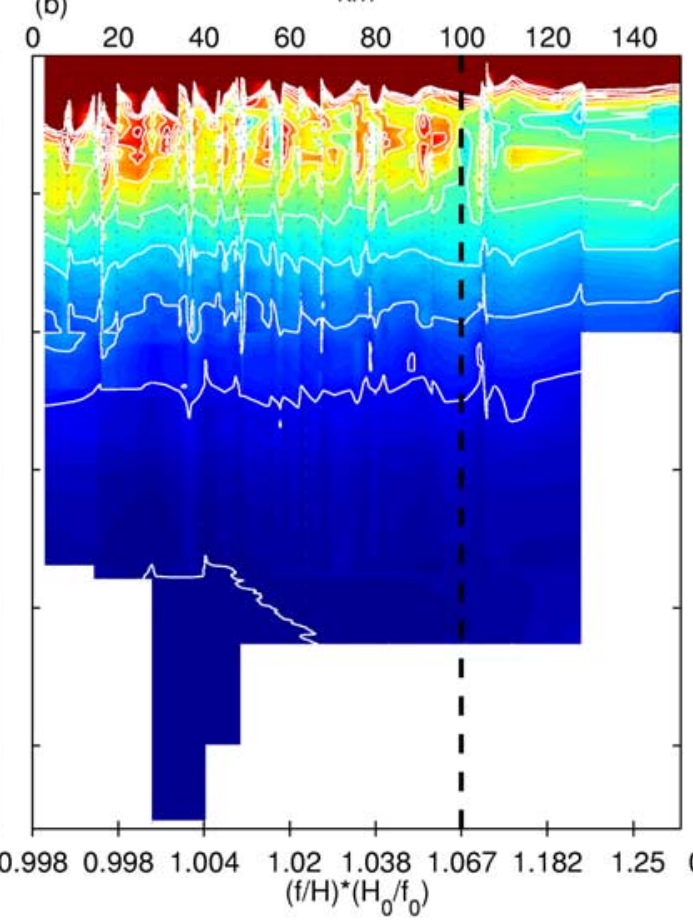

(c) $\mathrm{km}$

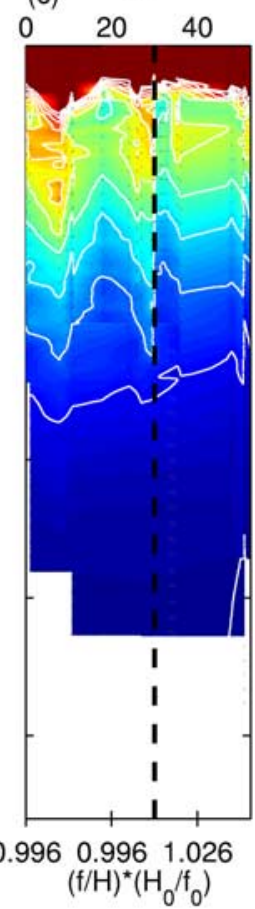

Figure 7. Distributions of potential temperature sections a, b, and c shown in Figure 6 according to $f / H$ values normalized by $f_{0}$ at $37^{\circ} 45^{\prime} \mathrm{N}$ and $H_{0}=2800 \mathrm{~m}$ (white contours every $0.1^{\circ} \mathrm{C}$ starting from $12.8^{\circ} \mathrm{C}$ ). Dashed thick lines separate the boundary circulation from the circulation in the basin interior. Profiles have been projected on the sections indicated on Figure 6. The origin for the distances is located in the interior of the basin. 


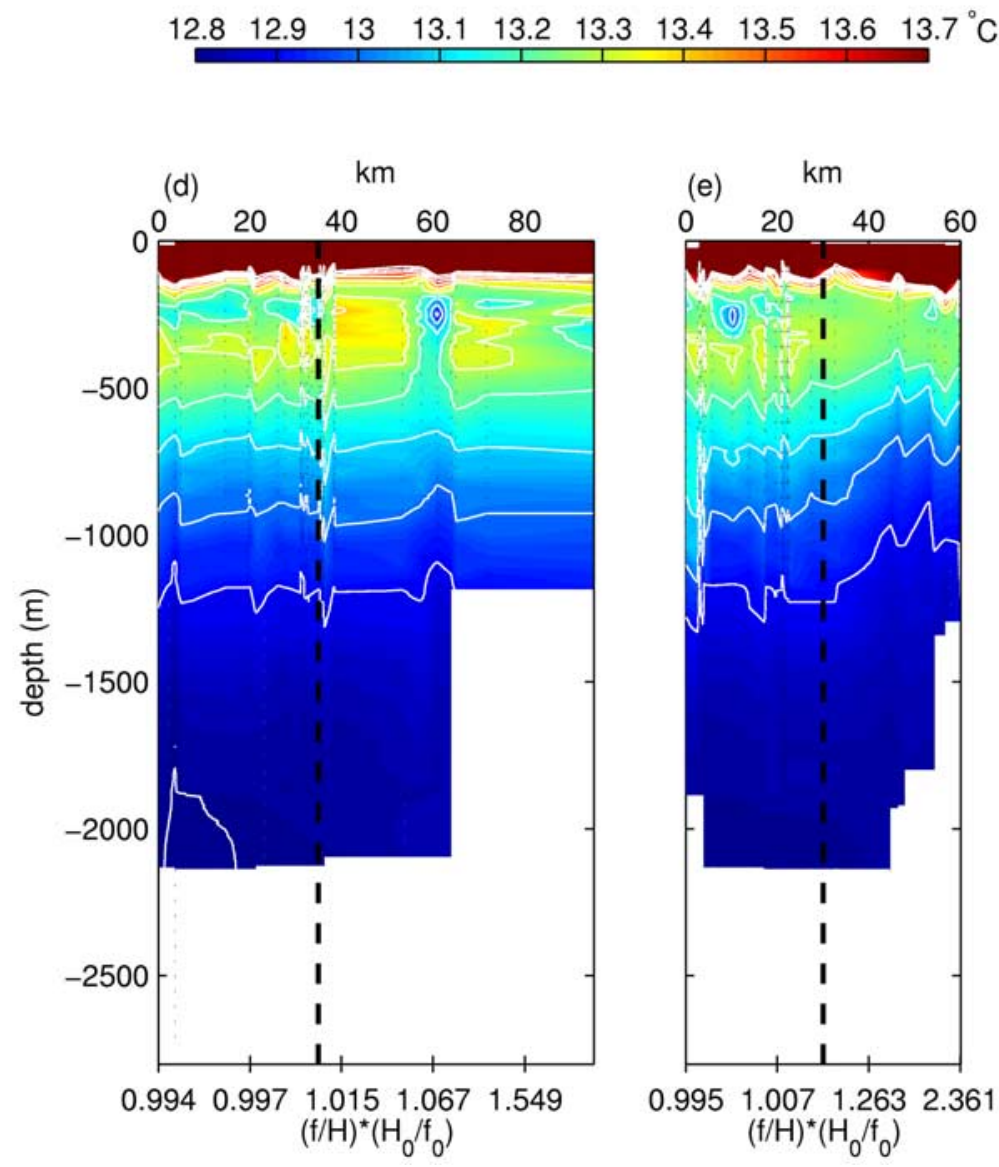

Figure 8. Distributions of potential temperature along sections $d$ and e shown in Figure 6 according to $f / H$ values normalized by $f_{0}$ at $37^{\circ} 45^{\prime} \mathrm{N}$ and $H_{0}=2800 \mathrm{~m}$ (white contours every $0.1^{\circ} \mathrm{C}$ starting from $12.8^{\circ} \mathrm{C}$ ). Thick dashed lines separate the boundary circulation from the circulation in the basin interior. Profiles have been projected on the sections indicated on Figure 6. The origin for the distances is located in the interior of the basin.

[36] From a hydrographic point of view one can thus distinguish two different overall regimes: (1) the boundary circulation confined to the continental slope with very distinct water properties and (2) the interior circulations where waters originating from the different boundaries mix together. These very different properties indicate boundary flows that are external to the cyclonic circulations observed in the basin interior. We will associate the Algerian Gyres with the circulations in the basin interior while we will use the term "boundary circulation" to denote flows of the distinct waters along the continental slope, which surround the Algerian Gyres.

\section{Velocity Distributions}

[37] The $f / H$ field can also be used to describe the velocity distributions characterizing the Algerian Gyres. For any location, one can define a local reference $\left(\overrightarrow{e_{t}}, \overrightarrow{e_{n}}\right)$ with one direction tangential, $\overrightarrow{e_{t}}$, and another one perpendicular, $\overrightarrow{e_{n}}$, to the $f / H$ contours. All the velocity measurements carried out between $36^{\circ} \mathrm{N}$ and $40^{\circ} \mathrm{N}$ and between $1^{\circ} \mathrm{W}$ and $4^{\circ} 30^{\prime} \mathrm{E}$ for the Western Algerian gyre and between $4^{\circ} 30^{\prime} \mathrm{E}-9^{\circ} \mathrm{E}$ for the Eastern Algerian Gyres have been projected onto these local coordinate directions $\left(\overrightarrow{e_{t}}, \overrightarrow{e_{n}}\right)$. They are plotted against the corresponding $f / H$ values in Figure 9. This approach is justified by the fact that Lagrangian trajectories and mean Eulerian currents mainly follow the $f / H$ closed contours. This representation of the flow is a way to analyze the common depth structure of the whole gyres.

[38] For both gyres the average velocities perpendicular to the contours is nearly zero (Figure 9, lower panels). In contrast, the tangential components (Figure 9, upper panels) appear to reproduce the two regimes described in section 6 based on hydrographic data: the boundary circulation along the slope with a constant velocity and the Algerian Gyres with a linear function of $f / H$ representing the basin interior. This offers an opportunity to represent the circulation in the

Table 2. Average Temperature Over the Layer $200-500 \mathrm{~m}$ for the Basin Interior for the Sections Presented on Figures 7 and $8^{\mathrm{a}}$

\begin{tabular}{ccccc}
\hline Section & $(f / H) /\left(f_{0} / H_{0}\right)$ Limit & $\operatorname{Mean}(\mathrm{T}),{ }^{\circ} \mathrm{C}$ & $\operatorname{Min}(\mathrm{T}),{ }^{\circ} \mathrm{C}$ & $\operatorname{Max}(\mathrm{T}),{ }^{\circ} \mathrm{C}$ \\
\hline $\mathrm{a}$ & 1.1 & $13.40 \pm 0.10$ & 13.32 & 13.78 \\
$\mathrm{~b}$ & 1.1 & $13.38 \pm 0.11$ & 13.14 & 13.66 \\
$\mathrm{c}$ & 1.1 & $13.35 \pm 0.07$ & 13.15 & 13.54 \\
$\mathrm{~d}$ & 1.0 & $13.25 \pm 0.02$ & 13.23 & 13.28 \\
$\mathrm{e}$ & 1.0 & $13.26 \pm 0.03$ & 13.19 & 13.30 \\
\hline
\end{tabular}

${ }^{a}$ Profiles characterized by a value lower than the $(f / H) /\left(f_{0} / H_{0}\right)$ limit are taken into account. 


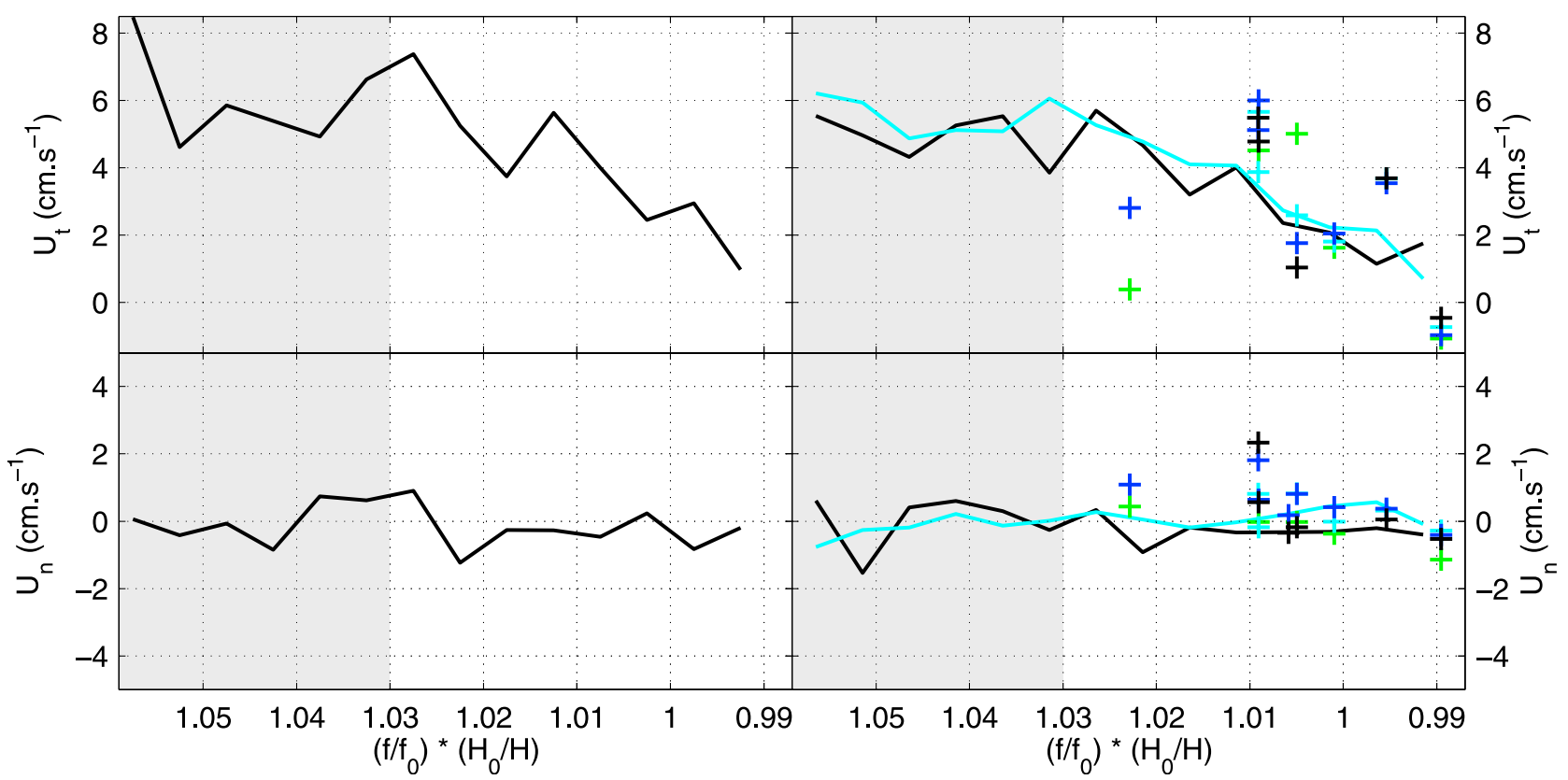

Figure 9. Velocity distributions of the Western (left) and Eastern (right) Algerian Gyres according to $f / H$ values normalized by $f_{0}$ at $37^{\circ} 45^{\prime} \mathrm{N}$ and $H_{0}=2800 \mathrm{~m}$ at different depths. Shaded areas correspond to the boundary circulation. Upper panels correspond to the component of the velocity tangential to $f / H$ contours, lower panels to the perpendicular one. These are average velocities in $f / H$ classes (starting from 0.99 with an increment of 0.005 ) from profiling floats at 1200 and $2000 \mathrm{~m}$ depth (black thick line), RAFOS floats at $600 \mathrm{~m}$ depth (blue thick line). Average velocities from moored current meters at $350 \mathrm{~m}($ green +$), 1000 \mathrm{~m}($ cyan +$), 1800 \mathrm{~m}$ (blue + ), and $2700 \mathrm{~m}($ black + ) depth are plotted at the $f / H$ value corresponding to the locations of the moorings. The origin for the distances is located in the interior of the basin.

southwestern Mediterranean Sea in a simple way. One can extract values from about $5 \mathrm{~cm} / \mathrm{s}$ at the periphery of the gyres $\left((f / H) /\left(f_{0} / H_{0}\right) \sim 1.03\right)$ down to $0 \mathrm{~cm} / \mathrm{s}$ at the $f / H$ minimum $\left((f / H) /\left(f_{0} / H_{0}\right) \sim 0.99\right)$. This range of $f / H$ values (0.99 to 1.03) corresponds to the basin interior (abyssal plain: Figures 1, 7d, and 8c) while much higher values of $f / H$ are associated with the boundary circulation (continental slopes southwest of Sardinia, south of Balearic Islands, and north of Algeria). For the boundary circulation $((f / H) /$ $\left.\left(f_{0} / H_{0}\right)>1.03\right)$, the average velocities are rather uniform with $f / H$, around $5 \mathrm{~cm} / \mathrm{s}$ on average.

[39] Rough estimates of the barotropic transports associated with the Algerian Gyres can be extracted from this synthetized description. Considering the mean distance between the $f / H$ minima at the center of the gyres and 1.03 (at the periphery of the gyres) and corresponding mean $H$, these velocity patterns lead to estimates of approximately $2 \mathrm{~Sv}$ and $3 \mathrm{~Sv}$ of barotropic recirculations in the basin interior for the Western and Eastern Algerian Gyres, respectively. However, this is only an empirical approximation since there is no reason to expect a linear uniform behavior from first-order dynamics.

[40] Individual currents may differ significantly from the mean profile (order of $5 \mathrm{~cm} / \mathrm{s}$ ) due to temporal and spatial variability. One process contributing to this is mesoscale currents. In addition, the spatial structure of the gyre do not match perfectly the $f / H$ field. This may be documented by the average velocities from the moored current meters on Figure 9 scattered around the average velocity distribution of the Eastern Algerian Gyre. For a given $f / H$ value, the velocities averaged over time appear to vary according to the location within a standard deviation $(5 \mathrm{~cm} / \mathrm{s})$ from the general pattern. There could also be acceleration effects due to variations in $\mathrm{flH}$ gradient along the path of a water parcel following a given $f / H$ contour (e.g., variations of the distance between closed contours) and slight deviations from the first-order barotropic potential vorticity balance (e.g., horizontal structures of the gyres in relative vorticity, effects of stratification). Finally, the above analysis does not take into account any temporal variability of the intensities of the gyres since all the measurements were used together from July 1997 to August 2002. A thorough description of all these effects was not possible with our data set because of its relatively coarse spatiotemporal coverage. However, they appear to be all second-order terms since the velocity structures for both gyres are similar to the $f / H$ geometry.

\section{Origin of the Algerian Gyres}

[41] The presence of closed $f / H$ isocontours (section 5) favor free barotropic circulations, with the water parcels conserving potential vorticity (at first order) along their trajectories within the Algerian Gyres. Without forcing or dissipation, a linear flow parallel to $f / H$ is possible within closed contours, whereas this "geostrophic mode" is absent when contours are blocked at the "walls" (the continental slope), which separate the land and the ocean [Greenspan, 1968; Welander, 1968; Hasselmann, 1982]. However, the 


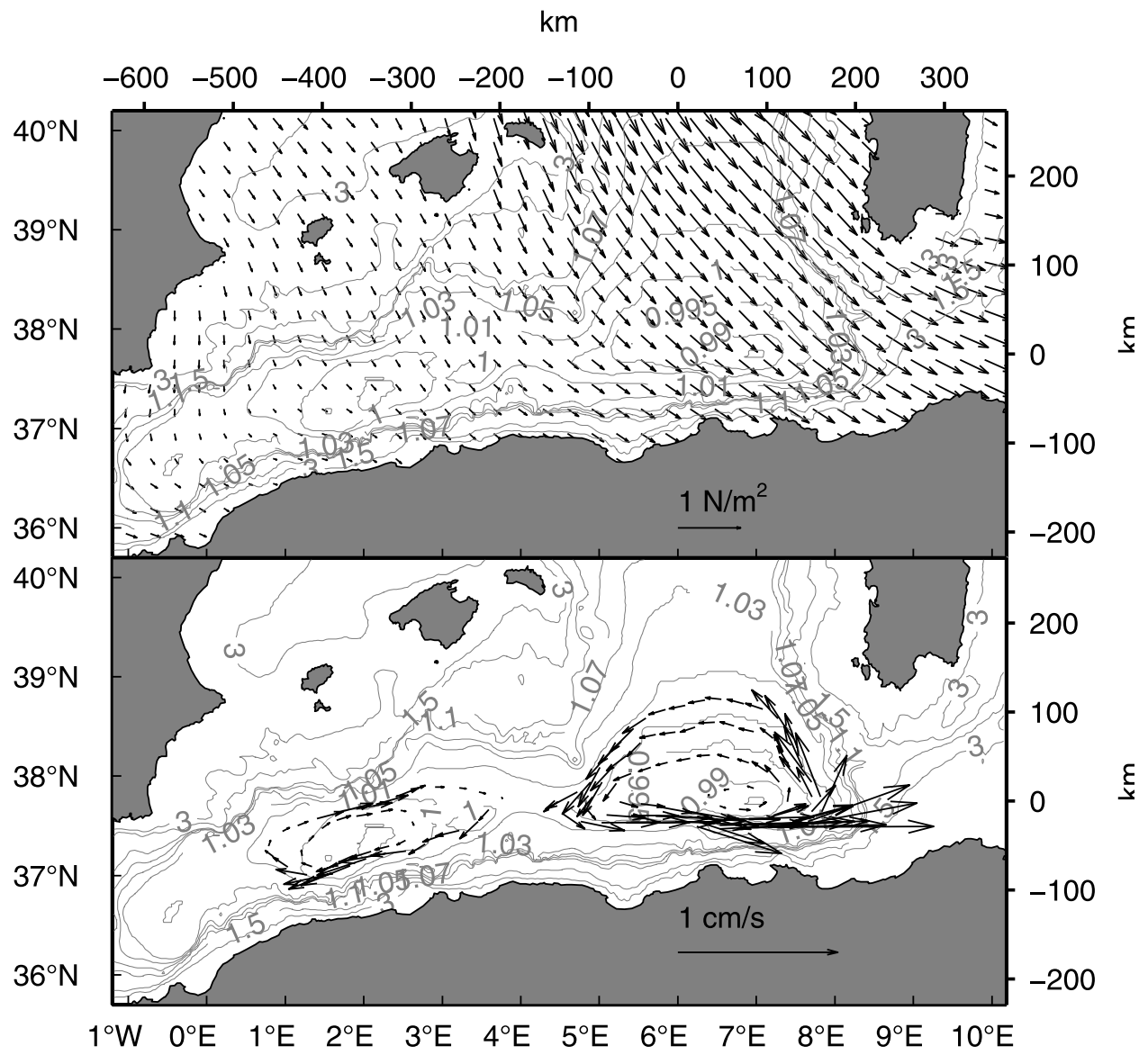

Figure 10. (top) averaged wind stress over the period 1998-2001 (which is included in our in situ observations period) from the European Center for Medium-Range Weather Forecasting (ECMWF $0.5^{\circ} \times 0.5^{\circ}$ spatial grid resolution). (bottom) barotropic circulation due to the local wind stress, scaling depends on the adjustable parameter $R$ (see text).

closed $f / H$ contours cannot explain the direction and the intensities of the circulations without taking into account forcing and friction.

\subsection{Local Wind Stress and Bottom Friction}

[42] The atmospheric forcing is a prime candidate for forcing these flows along closed $f / H$ contours. In the following, a barotropic linear model will be used to examine the role of the local wind. It is possible to construct a solution for the currents in a homogeneous fluid in a region of closed $f / H$ if the winds and bathymetry are known [Kamenkovich, 1962; Johnson and Hill, 1975; Johnson, 1998; Dewar, 1998; Isachsen et al., 2003]. A difficulty arises with stratification since momentum must be transferred through fluid layers downward to the bottom Ekman layer to balance the surface forcing. However, we assume that this stratification effect is not a first-order term considering the strong barotropic component characterizing the gyre circulations observed here and accordingly, we will restrict ourselves to the barotropic case. In addition we will consider here only the time-averaged wind stress $\vec{\tau}$ since the Algerian Gyres appear to be permanent features.

[43] In that case, the barotropic velocity $\vec{U}_{0}$ on a given $f / H$ contour, $\Gamma$, can be obtained by integrating the average wind stress around the contour assuming the bottom Ekman layer closes the mass balance

$$
\vec{U}_{0}=\frac{\oint_{\Gamma} \vec{\tau} /(\rho H) \cdot \overrightarrow{d l}}{\oint_{\Gamma}\left(R / H^{2}\right)(\vec{\nabla}(f / H) \cdot \vec{n}) d l} \frac{\vec{k}}{H} \times \vec{\nabla}\left(\frac{f}{H}\right),
$$

where $\rho$ is the density of water and $R$ represents the Ekman $\operatorname{drag}\left(R=(\nu f / 2)^{1 / 2}\right.$ with an effective kinematic viscosity $\left.\nu\right)$ as in the work of Isachsen et al. [2003].

[44] The velocities resulting from this model are parallel to the $f / H$ contours and inversely proportional to the friction coefficient $R$, which is a free parameter that can be adjusted. The direction of the computed flow depends directly on the sign of the wind stress curl. The mean forcing shape (Figure 10) is strongly influenced by Mistral and Tramontane winds blowing occasionally toward southeast over the Balearic Islands from the Gulf of Lions. The maximum wind velocities are over the Eastern Algerian Gyre. The wind stress is mainly cyclonic in the eastern part of the basin while it is anticyclonic in the western part. Thus this model predicts a cyclonic circulation in the basin interior for the Eastern Algerian Gyre and an anticyclonic circulation 
for the Western Algerian Gyre regardless of the friction coefficient $R$, which is in contradiction with the observed flows.

[45] Isachsen et al. [2003] found that a friction coefficient $R=5 \times 10^{-4} \mathrm{~m} \mathrm{~s}^{-1}$ is optimal for the Arctic and Nordic Seas. In our case, the corresponding decay timescales $T_{d} \sim$ $(H / R) \propto(H \rho u / \tau)$ are also around $1-2$ months using $H \sim$ $2800 \mathrm{~km}, \rho \sim 1028 \mathrm{~kg} \mathrm{~m}^{-3}, u \sim 5-10 \mathrm{~cm} \mathrm{~s}^{-1}$, and $\tau \sim 0.1$ $\mathrm{N} \mathrm{m}^{-2}$ which are typical values in the area. Using this friction coefficient and the bathymetry from Smith and Sandwell [1997] smoothed to avoid bathymetric scales smaller than $15 \mathrm{~km}$ (which is the scale of the deformation radius in this region), the computed velocities presented on Figure 10, are $0.3 \pm 0.2 \mathrm{~cm} \mathrm{~s}^{-1}$ for the Eastern Algerian Gyre and $-0.1 \pm 0.1 \mathrm{~cm} \mathrm{~s}^{-1}$ for the Western one on average over the outermost $f / H$ contours defining their peripheries. The maximum computed velocities along the contours were $1.2 \mathrm{~cm} / \mathrm{s}$ and $-0.4 \mathrm{~cm} / \mathrm{s}$ for the Eastern and Western Algerian Gyres, respectively. The largest values were obtained where the direct effect of the wind is amplified by strong values of $\nabla(f / H)$, reflecting the constraint of mass conservation along $\mathrm{flH}$ contours.

[46] This has to be compared to the observed and wellestablished velocities order of $4-5 \mathrm{~cm} \mathrm{~s}^{-1}$ characterizing these two barotropic and cyclonic circulations over the observing period. Consequently, the local wind forcing appears to be rather weak, if one assumes that the decay timescale of 2 months is the right order of magnitude for bottom friction. A decay timescale of 25-30 months would be more appropriate for the Eastern Algerian Gyre. However, the more $R$ is modified to make the model fit the observed velocities for the Eastern Algerian Gyre, the more the model will be wrong for the Western Algerian Gyre with the same value of $R$. One can argue that the bottom friction should not vary so significantly from the western part to the eastern part of the basin.

[47] In summary, the local wind does not appear as the driving mechanism for establishing such circulations. It reinforces the Eastern Algerian Gyre while it weakens the western one, and other physics which were not considered in this simple model must be responsible for establishing such circulations along the closed $f / H$ contours.

\subsection{Lateral Diffusion From the Boundaries}

[48] As shown in sections 6 and 7, the flow in the Algerian basin is characterized by two regimes. The cyclonic boundary circulation along the continental slope surrounds the Algerian Gyres. Therefore this along-slope circulation might provide the forcing for the Algerian Gyres. Owing to the configuration, the joint effect of all the boundary currents could be to induce cyclonic motions within the closed $f / H$ isocontours by lateral processes that were not considered in the above model.

[49] The hydrographic patchiness that one can see on Figures 7 and 8 in the basin interior implies entrainment of waters from the boundaries toward the basin interior. This indicates fluxes from the boundaries, where one can find the highest level of kinetic energy (Figure 9). Motions within the closed $f / H$ contours could thus be forced from there, via lateral diffusion of mass, momentum, and potential vorticity involving mesoscale and even smaller-scale features (filaments and internal waves).
[50] Mesoscale and small-scale activity constitutes a systematic and persistent forcing of the circulation of the entire ocean. Its relevance in modifying the transport and "viscous" properties of the large-scale circulation is widely recognized. What may be special here is the shape of the bottom topography (closing $f / H$ contours), which isolates the interior regimes and makes it more sensitive to eddy fluxes from the outside, which can act over a long time with only small competing effects.

[51] Dewar [1998] extended the models of Welander [1968] and Young [1981] to stratified fluids and considered a parameterization of the eddy fluxes by a downgradient diffusion of mean potential vorticity in addition to the wind forcing. He found a similar role for barotropic $\mathrm{fl} H$ contours and an inverse dependence of the flow on bottom drag. He suggested the circulation is more sensitive to eddy driving than to direct wind driving and that the sense of the circulation is determined by the sign of the topographic anomalies providing they can counteract the $\beta$-effect and close $f / H$ contours: highs and lows in the bottom elevation generate anticyclones and cyclones, respectively. Observations of the Zapiola Anticyclone and the anticyclonic circulation on the Azores Plateau in the Atlantic ocean illustrated his theory. He argued that the Zapiola Anticyclone is more intense than the circulation on the Azores Plateau because of the vicinity of the western boundary current generating intense eddy activity and lower bottom friction due to smoother topography. This theory shows that eddy fluxes of potential vorticity and/or momentum can drive the mean circulation within closed $f / H$ contours. We hypothesize that a similar process is at work for the generation of the Algerian Gyres.

[52] The relative contribution of the different boundary currents flowing around the Algerian Gyres is not clear yet and further studies are necessary since our data set did not allow us to address this point. They can all be involved in the establishment of such circulation through the generation of eddies (AEs, SEs,...) or even through smaller-scale mixing phenomena. Note that the Algerian Current is commonly described as 200-400 m deep, whereas the flow in the basin interior is barotropic at leading order. The Algerian Current could have an influence on the gyres through baroclinic instability processes which are able to move momentum vertically.

\section{Discussion}

[53] The role of the local wind stress has been investigated but does not appear as a determining factor for directly establishing such barotropic circulations. Instead, the Algerian Gyres are likely to be forced laterally by the general boundary circulation flowing at their periphery. This forcing is believed to occur through mesoscale and smallscale processes laterally diffusing kinetic energy and potential vorticity inward from the boundary currents. While not of local importance, the atmospheric forcing (wind stress and buoyancy fluxes) should not be ignored completely since it affects the general circulation of the Mediterranean Sea and in particular drives part of this along-slope boundary circulation of all water masses. Thermohaline forcing of the exchanges (1) between the Tyrrhenian Sea and the western Mediterranean basin through the Channel of Sardinia, (2) between the 
northern and southern basins, and (3) through the Strait of Gibraltar set the boundary circulation, which may thus indirectly affect the Algerian Gyres circulations.

[54] There are some important implications for numerical simulations of the Mediterranean circulation. Basin-scale models of low resolution $\left(1 / 4^{\circ}\right)$ were compared during the European MEDMEX project [Beckers et al., 2002]. None of them reproduced these gyres. The particular $f / H$ shape favoring the Algerian Gyres disappears in standard levels numerical models. The shape of the abyssal plain is not resolved well enough because of the coarse discretization of the deep layers. The $f / H$ contours in these models are all oriented west-east and blocked by vertical walls.

[55] A higher-resolution model $\left(1 / 16^{\circ}\right)$ developed in the context of the French Mercator project (P. Bahurel et al., personal communication, 2002) can reproduce the gyres [Nayagum et al., 2003; Béranger et al., 2004]. They appear to be rather weak but when this model is configured with a "partial cells" representation of the bottom topography [Pacanowski and Gnanadesikan, 1998], the gyres are well reproduced. With this configuration, the numerical model is able to take the gentle slope of the bottom topography into account in a more realistic way: $f / H$ contours are closed in the basin interior. This result is additional evidence for the dominant role of the closed $f / H$ contours of the abyssal plain in inducing the gyre circulations. A detailed analysis of these numerical aspects including the process driving the gyres will be presented in a forthcoming paper.

[56] In a more general context the model behaviors also support the results presented by de Miranda et al. [1999] concerning the Zapiola Anticycone and showing the importance of having a good representation of the dynamical effect of the bottom topography. In classical z-coordinate models, unphysical dissipation of vorticity by lateral friction is usually large at grid points adjacent to the sidewalls because horizontal vorticity gradients are forced to be large in the sidewall boundary layer in addition to the problem of the vertical resolution. This effect is reduced when using partial cells or sigma-coordinate following more closely the bathymetry. More importantly, these findings emphasize how the realism of operational products could be increased by first trying to improve the model dynamics. When a numerical model is intrinsically not capable to reproduce a main circulation feature as observed, an unnecessary number of observations would then be required to force the model to generate realistic products.

\section{Conclusion}

[57] Thanks to both Lagrangian and Eulerian measurements carried out in the framework of the MATER program, we have discovered new and important aspects of the general circulation in the western Mediterranean Sea. This study (1) confirms with additional data the large-scale cyclonic circulation observed for the first time at the beginning of MATER (the Eastern Algerian Gyre), (2) reveals the existence of a second cyclonic circulation located to the west (the Western Algerian Gyre), and (3) presents some diagnostics and hypotheses about the existence of these two gyres.

[58] The Algerian Gyres are mainly barotropic and characterized by velocities of about $5 \mathrm{~cm} \mathrm{~s}^{-1}$ at their periphery.
They are dominant features in the deep and intermediate layers where the mesoscale activity is much weaker than at the surface. They correspond to mean recirculations on the whole water column of around 2 and $3 \mathrm{~Sv}$, for the Western and the Eastern Algerian Gyres, respectively. Considering the period of time over which they were observed, they appear to be permanent circulation features characterizing the southwestern Mediterranean Sea.

[59] We related the Algerian Gyres to a strong topographic constraint closing the $f / H$ isocontours over the abyssal plain and favoring such circulations as free geostrophic modes. We argued that they are forced by the boundary circulation flowing along the continental slope and surrounding them, through lateral fluxes by mesoscale or even smaller-scale features. A consequence of the described processes and balances is that the Algerian Gyres should behave as buffer zones where all the different water masses originating from the boundaries recirculate and mix together. This would have an impact not only on the momentum and water property balances but also on the response and role of the southwestern Mediterranean Sea in reaction to climate-scale changes in the region.

[60] Acknowledgments. The MATER experiment has been funded by the European Union in the framework of the MAST3 program, under contract MAS3-CT96-0051. We acknowledge A. Lourenço and C. Rouault for their expertise in operating RAFOS floats and data processing. We also thank Michael Reich for the deployment of the profiling floats and for the data recovery and processing. We thank the captains and crews from R/V Tethys II (INSU-France), R/V Le Surolcirc;t (Ifremer-France), and R/V Poseidon (IFM-GEOMAR, Germany). Thanks to Météo-France and Mercator Project of Toulouse (France) to have provided the analyses of ECMWF over the 1998-2001 period.

\section{References}

Astraldi, M., F. Conversano, G. Civitarse, G. P. Gasparini, D. Ribera, M. Alcala, and A. Vetrano (2002), Water mass properties and chemical signatures in the central Mediterranean region, J. Mar. Syst., 33-34, $155-177$.

Ayoub, N., P.-Y. Le Traon, and P. De Mey (1998), A description of the Mediterranean surface variable circulation from combined ERS-1 and TOPEX/POSEIDON altimetric data, J. Mar. Syst., 18, 3-40.

Beckers, J. M., et al. (2002), Model intercomparison in the Mediterranean: MEDMEX simulations of the seasonal cycle, J. Mar. Syst., 33-34, 215251

Benzohra, M., and C. Millot (1995a), Characteristics and circulation of the surface and intermediate water masses off Algeria, Deep Sea Res., 42, $1803-1830$.

Benzohra, M., and C. Millot (1995b), Hydrodynamics of an open sea Algerian Eddy, Deep Sea Res., 42, 1831-1847.

Béranger, K., L. Mortier, and M. Crépon (2004), Seasonal variability of water transport through the Straits of Gibraltar, Sicily and Corsica, derived from a high-resolution model of the Mediterranean circulation, Progr. Oceanogr., 66, 341-364.

Bouzinac, C., J. Font, and C. Millot (1999), Hydrology and currents observed in the channel of Sardinia during the PRIMO-1 experiment from November 1993 to October 1994, J. Mar. Syst., 20, 333-355.

Bryden, H. L., and H. M. Stommel (1984), Limiting processes that determines basic features of the circulation in the Mediterranean Sea, Oceanol. Acta, 7, 289-296.

de Miranda, A. P., B. Barnier, and W. K. Dewar (1999), On the dynamics of the Zapiola Anticyclone, J. Geophys. Res., 104, 21,137-21,149.

Dewar, W. K. (1998), Topography and barotropic transport control by bottom friction, J. Mar. Res., 56, 295-328.

Font, J., C. Millot, J. Salas, A. Julia, and O. Chic (1998), The drift of Modified Atlantic Water from the Alborean Sea to the eastern Mediterranean, Sci. Mar., 62(3), 211-216.

Fuda, J. L., C. Millot, I. Taupier-Letage, U. Send, and J. M. Bocognagno (2000), XBT monitoring of a meridian section across the Western Mediterranean Sea, Deep Sea Res. I, 47, 2191-2218.

Gascard, J.-C., and C. Richez (1985), Water masses circulation in the Western Alboran Sea and in the Straits of Gibraltar, Progr. Oceanogr., $15,157-216$. 
Gascard, J.-C., C. Rouault, and P. Testor (1999), General ocean circulation and subsurface mesoscale eddies in the Algerian Basin, paper presented at the Fourth Mediterranean Targeted Project Workshop, MATER, Perpignan, France.

Greenspan, H. P. (1968), The Theory of Rotating Fluids, 327 pp., Cambridge Univ. Press, New York.

Hasselmann, K. (1982), An ocean model for climate variability studies, Progr. Oceanogr., 11, 109-208.

Hopkins, T. S. (1988), Recent observations on the intermediate and deep water circulation in the Southern Tyrrhenian Sea, Oceanol. Acta, 9, 41-50.

Isachsen, P. E., J. H. LaCasce, C. Mauritzen, and S. Häkkinen (2003), Wind-driven variability of the large-scale recirculating flow in the Nordic Seas and Arctic Ocean, J. Phys. Oceanogr., 33, 2534-2550.

Johnson, G. (1998), Deep water properties, velocities and dynamics over ocean trenches, J. Mar. Res., 56, 329-347.

Johnson, J. A., and R. B. Hill (1975), Three-dimensional model of the Southern Ocean with bottom topography, Deep Sea Res., 22, 745-751.

Katz, J. (1972), The Levantine Intermediate Water between the Straits of Sicily and the Straits of Gibraltar, Deep Sea Res., 19, 507-520.

Kamenkovich, V. M. (1962), On the theory of the Antarctic Circumpolar Current, Tr. Inst. Okeanol., 56, 245-306.

Lacombe, H., and P. Tchernia (1960), Quelques traits généraux de l'hydrologie Méditerranéenne, Cahiers Oceanogr. XII, 8, 527-547.

MAST3 (1999), EU final scientific report, MAS3-CT96-0051, IFREMER Ed., Brest, France.

Millot, C. (1985), Some features of the Algerian Current, J. Geophys. Res., 90, 7169-7176

Millot, C. (1987), Circulation in the Western Mediterranean Sea, Oceanol. Acta, 10, 143-149.

Millot, C. (1991), Mesoscale and seasonal variabilities of the circulation in the western Mediterranean, Dyn. Atm. Oceans, 15, 179-214.

Millot, C. (1997), Circulation off Algeria inferred from the Mediprod-5 current meters, Deep Sea Res., 44, 1467-1495.

Millot, C. (1999), Circulation in the Western Mediterranean Sea, J. Mar. Res., 20, 423-442.

Millot, C., and I. Taupier-Letage (2005), Additional evidence of LIW entrainment across the Algerian basin by mesoscale eddies and not by a permanent westward flow, Progr. Oceanogr., 66, 231-250.

Nayagum, D., B. Alhammoud, P. Testor, K. Béranger, and L. Mortier (2003), A "partial cells" general circulation model of the Mediterranean, paper presented at EGS-AGU-EUG Joint Assemb., Nice, France.

Pacanowski, R. C., and A. Gnanadesikan (1998), Transient response in a z-level ocean model that resolves topography with partial-cells, Mon Weather Rev., 126(12), 3248-3270.

Perkins, H., and P. Pistek (1990), Circulation in the Algerian basin during June 1986, J. Geophys. Res., 95, 1577-1585.

Puillat, I., I. Taupier-Letage, and C. Millot (2002), Algerian Eddies Limetime can near 3 years, J. Mar. Syst., 31, 245-259.

Rhein, M., U. Send, B. Klein, and G. Krahmann (1999), Interbasin deep water exchange in the western Mediterranean, J. Geophys. Res., 104 23,495-23,508

Robinson, A. R., and M. Golnaraghi (1994), The physical and dynamical oceanography of the Mediterranean Sea, in Ocean Processes in Climate
Dynamics: Global and Mediterranean Examples, NATO ASI Ser. C: Math. and Phys. Sci., vol. 418, edited by P. Malanotte-Rizzoli and A. R. Robinson, pp. 255-301, Springer, New York.

Ruiz, S, J. Font, M. Emelianov, J. Isern-Fontanet, C. Millot, J. Salas, and I. Taupier-Letage (2002), Deep structure of an open sea eddy in the Algerian Basin, J. Mar. Syst., 33-34, 179-195.

Salat, J., and J. Font (1987), Water mass structure near and offshore the Catalan coast during the winter of 1982 and 1983, Ann. Geophys., 5, 4954.

Sammari, C., C. Millot, I. Taupier-Letage, A. Stefani, and M. Brahim (1999), Hydrological characteristics in the Tunisia-Sardinia-Sicily area during spring 1995, Deep Sea Res. I, 46, 1671-1703.

Smith, W. H. F., and D. T. Sandwell (1997), Global seafloor topography from satellite altimetry and ship depth soundings, Science, 277, 19571962.

Sparnocchia, S., P. Picco, G. Manzella, A. Ribotti, S. Copello, and P. Brasey (1995), Intermediate water formation in the Ligurian Sea, Oceanol. Acta, 18(2), 151-162.

Swallow, J. C. (1955), A neutral-buoyancy float for measuring deep currents, Deep Sea Res., 3, 74-81.

Taupier-Letage, I., and C. Millot (1988), Surface circulation in the Algerian Basin during 1984, Oceanol. Acta, 9, 79-85.

Taupier-Letage, I., I. Puillat, P. Raimbault, and C. Millot (2003), Biological response to mesoscale eddies in the Algerian Basin, J. Geophys. Res., 108(C8), 3245, doi:10.1029/1999JC000117.

Testor, P., and J.-C. Gascard (2005), Large scale flow separation and mesoscale eddy formation in the Algerian Basin, Progr. Oceanogr., 66, $211-230$

Vignudelli, S. (1997), Potential use of ERS-1 and Topex/Poseidon altimeters for resolving oceanographic patterns in the Algerian Basin, Geophys. Res. Lett., 24(14), 1787-1790.

Welander, P. (1968), Wind-driven circulation in one- and two-layer oceans of variable depth, Tellus, 20, 1-15.

Young, W. (1981), The vertical structure of the wind-driven circulation, Tech. Rep. WHOI-81-89, 215 pp., Woods Hole Oceanogr. Inst. and Mass. Inst. of Technol. Joint Progr. in Oceanogr., Woods Hole, Mass.

K. Béranger, UME/DFR/ENSTA, Chemin de la Huniére, F-91761 Palaiseau Cedex, France.

J.-C. Gascard, Laboratoire d'Océanographie et de Climatologie: Approche Expérimentale et Numérique (LOCEAN), Université Pierre et Marie Curie, Boite 100, 4 place Jussieu, F-75006 Paris, France.

C. Millot and I. Taupier-Letage, Laboratoire d'Océanographie et de Biogéochimie (LOB), Université de la Méditerranée, BP 330, F-83507 La Seyne, France.

U. Send, Scripps Institution of Oceanography (SIO), University of California, San Diego, Mail Code 0230, La Jolla, CA 92093-0230, USA.

P. Testor, Leibniz-Institut fr Meereswissenschaften (IFM-GEOMAR), FB 1: Ozeanzirkulation und Klimadynamik, PO-P, Düsternbrooker Weg 20, D-24105 Kiel, Germany. (ptestor@ifm-geomar.de) 